\title{
Emerging Nigerian Megacities and Sustainable Development: Case Study of Lagos and Abuja
}

\author{
Ajah Ekpeni Obia ${ }^{1}$ \\ ${ }^{1}$ Architecture Department, Cross River University of Technology, Calabar, Nigeria \\ Correspondence: Ajah Ekpeni Obia, Architecture Department, Cross River University of Technology, Calabar, \\ Nigeria. E-mail: ajekobi@yahoo.com
}

$\begin{array}{lc}\text { Received: July 20, } 2015 & \text { Accepted: August 8, } 2015 \quad \text { Online Published: February 15, } 2016 \\ \text { doi:10.5539/jsd.v9n2p27 } & \text { URL: http://dx.doi.org/10.5539/jsd.v9n2p27 }\end{array}$

\begin{abstract}
It is estimated that by 2020 half of Nigerians shall live in urban centres. Nigeria has scores of such centres, with many showing the tendency of becoming megacities in a no distant future. One of these cities, Lagos (already a megacity), shall by projection, have a population of 24 million persons by 2020 . The other, Abuja, is one of the fastest growing cities on earth. Generally, the world is now known to parade far larger cities than history has ever recorded. Some of these cities are quite magnificent and glorious - London, Paris, Tokyo and New York. On the other hand, Lagos and Mumbai are classic examples of urban failures. What separate the two classes of cities are the approaches to the design of their urban fabrics and management of their ecology. Whereas the former cities have adopted robust sustainability principles in their architecture and urban design/regeneration as well as efficient urban management programmes, the latter appear to be partially or totally non-committal. This paper examines the evolving Nigerian mega cities and their potentials for sustainable survival, with particular reference to Lagos and Abuja, using indices of economic productivity, social equity and environmental concerns. The result shows that the two cities failed these sustainability tests. The cause is traceable to unsustainable architecture being practiced. About half of the total global energy consumption comes from buildings. Eco-design prescriptions of the architect would guarantee urban sustainability. Thus, this paper recommends a national green building code for Nigeria.
\end{abstract}

Keywords: eco-cities, mega-cities, sustainability, affordable-housing, sustainable architecture

\section{Introduction}

The World today might safely be described as an 'urban planet' and her citizens as homo urbanis (Whitehouse, 2005). Evidences abound everywhere. More than half of the world population (54\%) is already living in urban settlements (Kraas et al., 2005; Angel., Sheppard, \& Civco, 2005 \& UN, 2014), and the factors that drive humans to the city are not abating, both in number and intensity- hunger, search for social amenities and better economic and educational opportunities amongst others. By 1800, only 3 per cent of humankind lived in cities and 14 per cent a century later (Ujoh, Kwabe, \& Ifatimehin, 2010). In 1950 there were 83 cities with population of one million and by 2007 the number rose to 468 (Megacities, 2010), Global urban population has risen from 746 million in 1950 to 3.9 billion in 2014 (UN, 2014). This increase, according to World Urbanization Prospects by UN DESA's Population Division, shall occur in India, China and Nigeria; the three countries contributing 37 per cent of the projected growth (UN, 2014). According to UN DESA (UN, 2014), by 2050 the projected urban population in Nigeria shall be 212 million.

Following the United Nations classification, there will likely be a preponderance of such cities soon in Nigeria, but these potential agglomerations are least prepared for their new roles. The irony is that not one of these Nigerian cities has an updated and honoured master plan (which could have led to a workable spatial plan), least of all one with sustainability agenda (Ahianba, ,Dimuna, \& Okogun, 2008). This paper examines the evolving Nigerian mega cities and their potentials for sustainable livability with particular reference to Lagos and Abuja. Existing data and trends have shown that Lagos and Abuja have failed in all the positive indexes of sustainability (Oresanya, 2008; Falade, 2010; Jibril, 2006 \& UNDP, 2003).

This paper thus equally examines the principles of sustainability and urban regeneration in the management of cities and how the Nigerian nation has responded to this modern day elixir. Of special concern in this write-up, is the role of the Nigerian architects and urban planners in finding solutions to the problems of urban decay and 
high energy demands in homes, offices and factories. The paper therefore calls on governments at all levels, professional bodies such as Nigerian Institute of Architects and their urban and building counterparts, and civil societies to evolve sustainability rules in city building and management.

\section{Conceptual Framework}

\subsection{Mega-cities}

There are various definitions of what constitute a mega-city depending on the parameters used. United Nations define mega city as a city with population of 10 million persons and above (Megacities, 2010), whereas Kraas et al, (2005) put the figure at 5 million. However, the expression has been used in Canada and other places to refer to conurbation of cities or communities that have hitherto been isolated but have circumstantially grown to link themselves (Megacities, 2010). Mega-cities are just more than large cities. They are the focal points of globalization as well as driving forces of development, 'connecting the best and the worst' (Kraas et al, 2005 \& Castells, 1996). They are the concentrations of wealth and power, a fact that underpins their political realities. They are the products of unrelenting urbanization.

The last few decades have experienced a wave of urbanization unlike any other in the past (Olujimi, 2009 \& Donk, 2006). The present urbanization drive is influenced and fostered by mass migration and the electronic media, both of which are interconnected (Urban Planet: Collective Identities, Governance and Empowerment in Megacities, 2010), in addition to the extreme poverty in the rural communities, especially in the third world nations. Urbanization processes that eventually lead to agglomerations are promoted mostly by population shift from rural to urban areas, and the inducements are great. Urban residents are privileged to have better and higher education level, higher income, lower fertility rate, better health and longer life than rural dwellers (Decker, Elliot, Smith, Blake \& Rowland, 2000).

Migrations into cities tend to loosen traditional loyalties, customs and kinships relations; however, urbanization reconfigures these traditional ties into new patterns. Populist, religious and ethnic movements for instance, have to struggle to occupy new social spaces in these urban set-ups. These processes of migration promote the insurgence of slums. As at today, 50 percent of the world urban communities live in slums. Higher rates are found in cities of Mumbai (55\%) and Lagos (70\%) (UNDP, 2003). This drive to cities often comes in rates and volumes that outstretch urban infrastructure and overwhelm city designers. For instance, most water treatment plants were constructed many decades ago with capacities far below their current demands. Municipal sewage treatment plants are rare and outdated. Existing landfills are full and there are no lands for the development of new ones. Solid waste treatment and recycling plants are just making their entry into the cities, and so far they are few.

Mega-cities depend on human and natural resources for their energy, industry, construction, infrastructure and maintenance. These demands that are huge have severe impact, both locally and globally. The total of these demands that will satisfy the cities constitute their 'ecological footprints' (Kraas et al, 2005). Generally, mega cities are classified into three categories (Kraas et al, 2005). These include those that are experiencing very rapid population growth, have outdated or non-existent infrastructure, and are located in developing countries or emerging markets. Examples of such cities include Mumbai (India), Lagos (Nigeria) and Jakarta (Indonesia). The second class involves those cities that are experiencing economic growth, establishing or transforming their infrastructure, already have strong economies and are undergoing a transition to developed cities, example of which include Shanghai (China) and Beijing (China). A third category includes those that are already developed and have strong and good infrastructure. In this group are found New York (America), Tokyo (Japan) and London (Britain), the alpha cities. Each of these categories has peculiar problems to face. While Tokyo, for instance will be struggling with the problems of aging population, Lagos is battling with the problems associated with slums and squatter settlements - poor health, squalid living conditions, insufficient/dilapidated infrastructure and poor waste management amongst others. 
Table 1. Population size and urban agglomerations as of 1 July, 2014

\begin{tabular}{|c|c|c|c|c|c|}
\hline Rank & Megacity & Country & Continent & Population & Annual Growth \\
\hline 1. & Tokyo & Japan & Asia & $37,833,000$ & $0.60 \%$ \\
\hline 2. & Delhi & India & Asia & $24,953,000$ & $3.20 \%$ \\
\hline 3. & Shanghai & China & Asia & $22.991,000$ & $3.40 \%$ \\
\hline 4. & Mexico City & Mexico & N. America & $20,843,000$ & $0.80 \%$ \\
\hline 5. & Sao Paulo & Brazil & S. America & $20,831,000$ & $1.40 \%$ \\
\hline $6 .$. & Mumbai (Bombay) & India & Asia & $20,741,000$ & $1.60 \%$ \\
\hline 7. & Osaka & Japan & Asia & $20,123,000$ & $0.80 \%$ \\
\hline 8. & Beijing & China & Asia & $19,520,000$ & $4.60 \%$ \\
\hline 9. & New York City & USA & N. America & $18,591,000$ & $0.20 \%$ \\
\hline 10. & Cairo & Egypt & Africa & $18.419,000$ & $2.10 \%$ \\
\hline 11. & Dhaka & Bangladesh & Asia & $16,984,000$ & $3.60 \%$ \\
\hline 12. & Karachi & Pakistan & Asia & $16,126,000$ & $3.30 \%$ \\
\hline 13. & Buenos Aires & Argentina & S. America & $15,024,000$ & $1.30 \%$ \\
\hline 14. & Kolkata & India & Asia & $14,766,000$ & $0.80 \%$ \\
\hline 15. & Istanbul & Turkey & Europe \& Asia & $13,954,000$ & $2.20 \%$ \\
\hline 16. & Chongqing & China & Asia & $12,916,000$ & $3.40 \%$ \\
\hline 17. & Rio de Janeiro & Brazil & S. America & $12,825,000$ & $0.80 \%$ \\
\hline 18. & Manila & Philippines & Asia & $12,764,000$ & $1.70 \%$ \\
\hline 19. & Lagos & Nigeria & Africa & $11,614,000$ & $3.90 \%$ \\
\hline 20. & Los Angeles & USA & N. America & $12,308,000$ & $0.20 \%$ \\
\hline 21. & Moscow & Russia & Europe & $12,063,000$ & $1.20 \%$ \\
\hline 22. & Guangzhou & China & Asia & $11,843,000$ & $5.20 \%$ \\
\hline 23. & Kinshasa & DRC & Africa & $11,116,000$ & $4.20 \%$ \\
\hline 24. & Tianjin & China & Asia & $10,860,000$ & $3.40 \%$ \\
\hline 25. & Paris (aire urbaine) & France & Europe & $10,764,000$ & $0.70 \%$ \\
\hline 26. & Shenzhen & China & Asia & $10,680,000$ & $1.0 \%$ \\
\hline 27 & London & United & Europe & $10,189,000$ & $1.20 \%$ \\
\hline 28. & Jakarta & Indonesia & Asia & $10,176,000$ & $1.40 \%$ \\
\hline
\end{tabular}

Source: World urbanization prospects: the 2014 revision

Today, about 28 settlements in the world are classified as mega-cities. These 28 cities are homes to 453 million people $-12 \%$ of global population (UN, 2014.)..Cities in developing nations and emerging markets account for about $95 \%$ of the earth's urban growth (Urban Planet: Collective Identities, Governance and Empowerment in Megacities, 2010). As at today, only three of these megacities, Lagos (Nigeria), Cairo (Egypt) and Kinshasa (Democratic Republic of Congo) are found in Africa but given the growth rates of African towns, it will not be long before they level with Asia's. Lagos, with a population of 12 million has a growth rate of $3.9 \%$, whereas Tokyo, the world's largest megalopolis, with a population of 38 million, has a growth rate of $0.6 \%$, less than that of Lagos by a factor of 6.5 ! Generally, the mega-cities of the developed world have low population growth rates - Moscow (Russia), 1.2\%, London (United Kingdom), 1.2\%; New York (United States), 0.2\% whereas the fastest growing cities are found in the developing nations -Dhaka (Bangladesh), 3.6\%, Karachi (Pakistan), 3.3\%, Delhi (India), 3.2\%, etcetera (see Table I) (UN, 2014).

\subsection{Determining Indices of Sustainable Development of Mega-Cities}

A mega-city's success could be measured in terms of its economic productivity, social equity and environmental diversity. The term 'environmental diversity' encompasses diverse land use as well as 'artificial biotypes' and 
these render mega-cities attractive and more stable (Kraas et al, 2005). In emerging markets and developing economies, mega-cities are known to grow faster than their infrastructure base. That is so because the rate of population drift to the cities of this developing nations is often quite high, and with low budgetary allocation, it is often not possible to provide the necessary infrastructure to cater for the influx. High concentration of industrial production, ecological overloads, unregulated and disparate land property market and insufficient housing development are common indices of badly managed urban settlements. (Kraas et al, 2005 \& Al-Akkham, 2012)

The goal of sustainable/eco-societies is to manage, reduce, or reverse some of the worst problem manifesting in burgeoning urban communities. The associated urban problems are found both in the cities of the developed as well as developing nations, though to varying degrees. They are most obvious in emerging market cities like Lagos (Nigeria), São Polo (Brazil) and Karachi (Pakistan), where infrastructure are non-existent, or are obsolete and/or poorly developed. Examples include such places like Ajegunle in Lagos and the slums of Karachi where pipe-borne water and toilet facilities are non-existent The ultimate goal of sustainable development is to make cities safe and pleasant places to work, live and raise children 'without undermining the ability of future generations to do the same' (Kraas et al, 2005). There are different solutions being canvassed by experts, some market based, some technological and some environmental in approach but non compares with 'sustainable development (Kraas et al, 2005).

The world's response to urban crises is the setting up of 'Local Agenda 21' by the International Council for Local Environmental Infrastructure (ICLEI) and launched at the 1992 Earth Summit. 'Local Agenda 21' is defined as a "participatory, multi-sector process to achieve the goals of Agenda 21 at the local level through the preparation and implementation of a long-term strategic action plan that addresses, as a matter of priority, local sustainable development concerns" (Desai, 1999). The Local Agenda 21 has brought together many cities and over 2000 communities and towns in 64 countries and this could be identified as Local Agenda 21 cities.

\subsection{Urban Regeneration}

Globally, problems of urban centres are now being addressed through the policy of urban regeneration or urban renewal. The parallel strand of this new concept in urban development is sustainable development, and there have been little co-ordination between the two, with greater imbalance towards urban regeneration (Al-Akkam, 2012 \& Couch \& Dennemann, 2000). The object of regeneration in the main involves the bringing of land and buildings into effective use, encouraging the development of existing and new industries/commerce, thus creating an attractive environment (Al Akkam, 2012 \& Department of Environment, Local Government, 1980). Urban regeneration encourages compact city development. However, according to Neuman (2005), 'sustainable urban development runs counter to the principles of the compact city in one fundamental respect, the primacy of process over form'. Compact cities afford the advantage of effective utilization of space but also concentrate environmental problems. Some of the emergent environmental problems include pollution from non-point sources due to daily activities of the concentrated population - flushing and clearing, cooking and washing and exhaust gases from vehicles, etcetera. There has to be a balance between the two prime concepts essential in the future survival of global megacities. The new concept gaining universal acceptability in urban development and regeneration is what is termed 'compact sustainable cities' development.

\subsection{Sustainability and Sustainable Architecture}

The World Commission on Environment and Development (WCED), headed by Gro Harlem Brundtland, in 1987 defined 'sustainable development' as 'development which meets the needs of the present generation without compromising the ability of future generation to meet their own needs' (WCED, 1987). It has been described as 'omni disciplinary'; it cannot be limited to a number of disciplines or areas, 'but is applicable to the whole world and everyone and everything in it, now and in the future' (Hui, 2002). This universal definition rests on two conceptual planks, the concept of 'needs' and 'limits'. 'Needs' in this case comprise the conditions for the maintenance of acceptable lifestyle for everyone on earth while 'limits' suggest the capacity of the environment to fulfill the needs of the present and the future, determined by our social organization and levels of technology (Obia \& Okon, 2010). These needs consist of our basic requirements as food, clothing, housing and employment. The 'limits' consist of the materials limitations such as finite resources and declining productivity caused by over exploitation of resources, depleting water quality and quantity, and shrinking biodiversity.

Ecologically, sustainability describes how the biological systems can be productive over time while maintaining their diversities; for humans, it suggests long term maintenance of well-being that depends equally on the well-being of natural ecosystem and the use of natural resources in responsible ways. The architect is a modifier of environment and he/she often does this by changing the configuration of the landscape, and using resources from the environment. These good-intentioned actions of the architect are bound to impact negatively on the 
environment. This has led to the thought of 'green building' or 'sustainable building' as well as 'sustainable construction' and 'sustainable design', and hence the concept of 'sustainable architecture'.

A 'green building' is a 'structure that is designed, built, renovated, operated, or re-used in an ecological and resource efficient manner' (Dick, 2010). Another definition looks at 'sustainable building' or 'green building' as 'building practices, which strive for integral quality (including economic, social and environmental preferences), in a very broad way' (Hui, 2002). Sustainable architecture aims at resource efficiency, energy efficiency (through reduction in the use of embodied energy materials), pollution prevention, harmonization with the environment and integrated and systemic approaches. At the urban level, it has led to the promotion of what is popularly called Sustainable City Programmes (SCP) by the United Nations (Ogu, 2000). Sustainable city programme was first applied in Ibadan in 1992, and then followed by Kano and Enugu. The projects failed because of lack of commitment on the part of municipal authorities (Ogu, 2000 \& Olumiji, 2009).

\subsection{The Role of the Architect/Urban Designer in Fostering Sustainable Mega-Cities' Development}

As should be expected, many mega-cities have reached their limits, both physical and managerial. Mega-cities running out of space imply prohibitively high urban land prices, leading to intensification of land use, resulting in the development of more high-rise buildings at the surface and underground spaces (Kraas et al, 2005). The skyscraper is a classic demonstration that we now operate in 3-dimensions rather than two. Maximum use of space in a compact development suggests that those skyscrapers, elevated roads and railways, communication and energy corridors and a lot of other places where people live, trade and work are built on, and above this surface.

Some of the strongest augments against sprawling include the economic and environmental cost of transportation, high productivity cost and uneconomical land use pattern. Compact cities, the opposite of sprawls, tend to be the answer to these posers. Compact development will mean a 3-D visualization of surface and sub-surface conditions, including their resources hazards. Underground may provide the environment suitable for public and commercial activities; however, there are dangers of unknown subsurface conditions. This 3-dimensional invasion of urban space requires the best of design of urban infrastructure. Most megacities today need urban regeneration or urban renewal to conform to the demands of sustainable cities. Urban regeneration approach is similar to the one adopted in the development of a new city, principally, the objective being to reduce 'ecological footprint'.

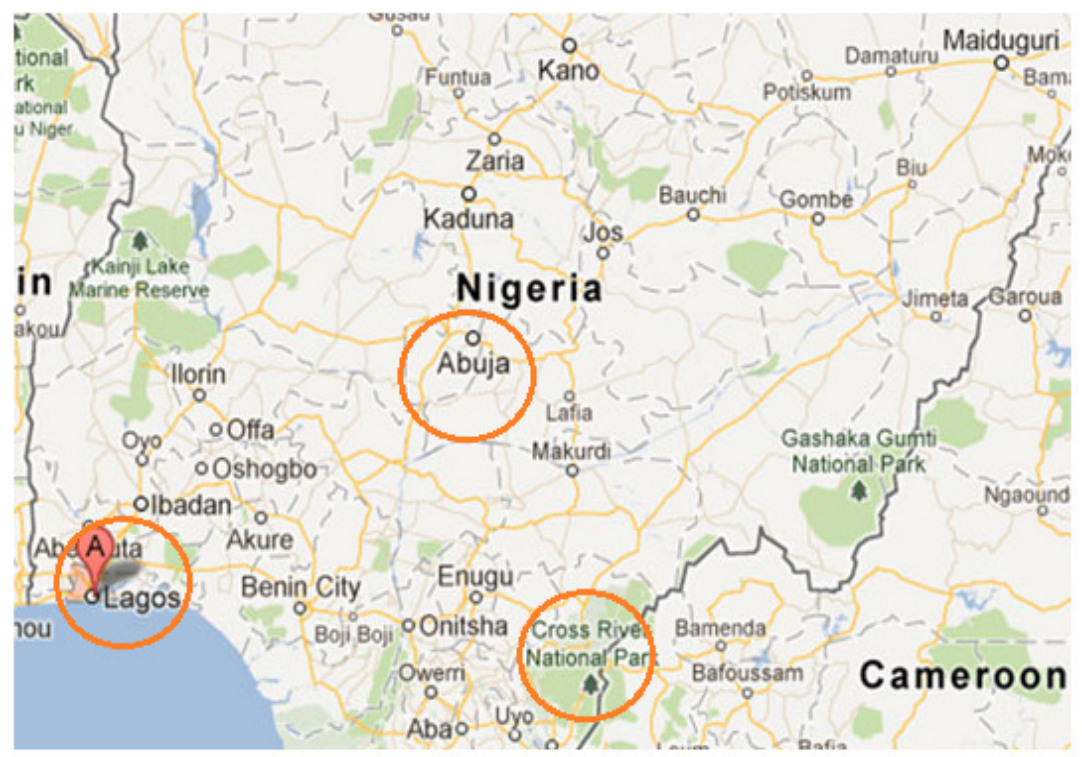

Figure 1. The map of Nigeria showing Abuja and Lagos (the case study areas), and Cross River Rainforest (where the bulk of the wood for the construction of Abuja was extracted)

Source: Commons. Wikimedia.org/wiki/File:Lagos_Map.PNG

Ecological footprints' of urban areas, 'the total amount of materials and services needed to sustain the settlements', extend to their bioregions where food and the materials for the construction of houses and other infrastructure are extracted from. This poses a great challenge to the architect as a prime consultant in the city 
design. The volume of construction in Abuja (the virgin capital city of Nigeria) in its first phase of development, for instance, was quite enormous. The large amount of wood used in the construction of houses and other structures did not come from Abuja and its immediate environs. Rather, they came from far places like Cross River rain forest, some 600-kilometre distance (see Figure 1). The extraction of this wood has led to a severe impact on the environment, including deforestation. The cut down forest was supposed to be a global 'sink' of carbon dioxide, a waste bi-product of industrial production processes. All these have added to the classification of Abuja as an expensive and non-sustainable emerging megacity.

The architect, by choice and calling, is a modifier of environment and in some way, a regulator of behavioural patterns of people at homes and in cities. His/her wayfinding design decisions regulate human and vehicular flow within our urban spaces. The architect's choice of form could become a cultural identity of a people; while the handling of the form and shape of the building shell (envelope) could determine occupants' behaviours within and outside the micro-environment of an enclosed space. Equally, the choice of building materials and processes go a long way to determining the fate of the natural and man-made environments and the overall well-being of the community. For instance, architects could source for alternative concrete binders to cement, a notorious energy-intensive essential construction material. They might specify other walling materials with large thermal massing instead of sandcrete blocks. Still further, there could be a large savings in labour and binders if inter-locking blocks are specified for building walls. Specification of local building materials would reduce embodied energy content of a building and the overall ecological footprint. Bamboo architecture could be an answer to the three attributes of sustainability - economics, social and environmental factors.

Bamboo, though light, can relatively be comparable to steel and concrete in tensile and compressive strengths (Esteve-Sendra, Moreno-Cuesta, Portates-Maianos, Magal. \& Royo, 2012 \& Kati, 2014). Second, in terms of its ecological gains, bamboo is biodegradable and regenerates much faster than traditional woods, and is found in abundance in Nigeria. It also has greater potential to absorb large amount of carbon dioxide than wood, absorbing $40 \%$ carbon dioxide while releasing $35 \%$ oxygen into the atmosphere (Wooldridge, 2012). It is estimated that buildings account for $1 / 6$ of the global fresh water consumption, $1 / 4$ of its wood harvest and $2 / 3$ of the world materials and energy flow (Roodman \& Lenssen, 1995). Buildings are also the biggest emitters of green house gases, GHG (Mourshed \& Khattah, 2006). A reduction in the use of these materials by half through thoughtful design would greatly improve the quality of life in the urban settings, clean the atmosphere and save the planet.

Through proper choice of materials and efficient design approach, the embodied energy involved in the construction of the building can be drastically lowered. The term embodied energy means "An assessment that includes the energy required to extract raw materials from nature, plus the energy used in primary and secondary manufacturing activities to provide a finished product..." (Mumma, 1995).

\section{Case Studies}

\subsection{The Emerging Mega-Cities of Nigeria}

Nigeria had been largely a rural nation, with most of her citizens living in rural areas. Many of these cities were small with less than half a million people until about early 1970s when the country began to experience urban growth spout (see Table 2). The end of the civil war in 1970 coupled with the new found oil wealth pull Nigerians from rural settlements into the cities, and the city of Lagos took the lion share, growing at $14 \%$ as against 2.3\% recorded against other Nigerian towns then (George, 2010). 
Table 2. Urban population in Nigeria 1921-2025

\begin{tabular}{llll}
\hline 1921 & Total population (in millions) & \% Rural & \% Urban \\
\hline 1921 & 18.63 & 95.2 & 4.8 \\
1931 & 19.93 & 93.3 & 6.7 \\
1953 & 30.30 & 90 & 10 \\
1963 & 55.65 & 80.3 & 19.2 \\
1973 & 79.76 & 78 & 22 \\
1983 & 84.70 & 75 & 25 \\
1991 & 88.50 & 68 & 32 \\
1996 & 102.52 & 60 & 40 \\
2000 & 128.8 & 56 & 44 \\
2005 & 147.6 & 51.8 & 48.2 \\
2010 & 168.4 & 48 & 52 \\
2015 & 190.9 & 44.9 & 55.1 \\
2020 & 214.5 & 41.8 & 58.2 \\
2025 & 238.4 & 39.1 & 60.9 \\
\hline
\end{tabular}

Sources: Nigeria Population Censuses; Federal Office of Statistics, Lagos, 1963 and 1970; Mabogunje, 1974,p.10; http://www.unhabitat.org/habrdd/conditions/wafrica/nigeria.htm

Note: Urban Population is defined in terms of settlement above 20,000 population in Nigeria

With a growth rate of 20-30\%, many Nigerian cities now have populations of more than 500,000, with some such as Ibadan, Kano, Port Harcourt, Kaduna, Benin and Maiduguri being up to 1 million and above. Ibadan and Kano in particular are near to 5 million (UNDP, 2003). Much of this growth is found in the 36 state capitals where there are huge government presences. The UN Habitat programme manager in Nigeria, Prof. Johnson Falade (2010) stated recently that 56 million (70\%) of the country's urban dwellers live in slums, with $54 \%$ of the population bellow poverty level. While Lagos and many of these cities grow naturally out of small settlements, Abuja was deliberately designed and built to correct the ills found in these other urban centres. In this paper, Lagos and Abuja are slated for critical examination, being representatives of Nigerian cities since all of them share common characteristics (Fig. 1).

\subsubsection{Lagos}

Lagos megacity is Nigeria's largest city and is situated within latitudes $6^{\circ} 23^{\prime} \mathrm{N}$ and $6^{\circ} 41^{\prime} \mathrm{N}$ and longitudes $2^{\circ} 42^{\prime} \mathrm{E}$ and $3^{\circ} 42^{\prime} \mathrm{N}$ (see figure 2). In 1871, Lagos was a village perched on an island with a population of 28,578 persons and an area of $4 \mathrm{~km}^{2}$ (George, 2010). However, by 1952 this figure rose to 346,137 , while barely 10 years after the population rose to 1,122,733 in 1963. Today, Lagos has 12 million inhabitants (see Table 1). 


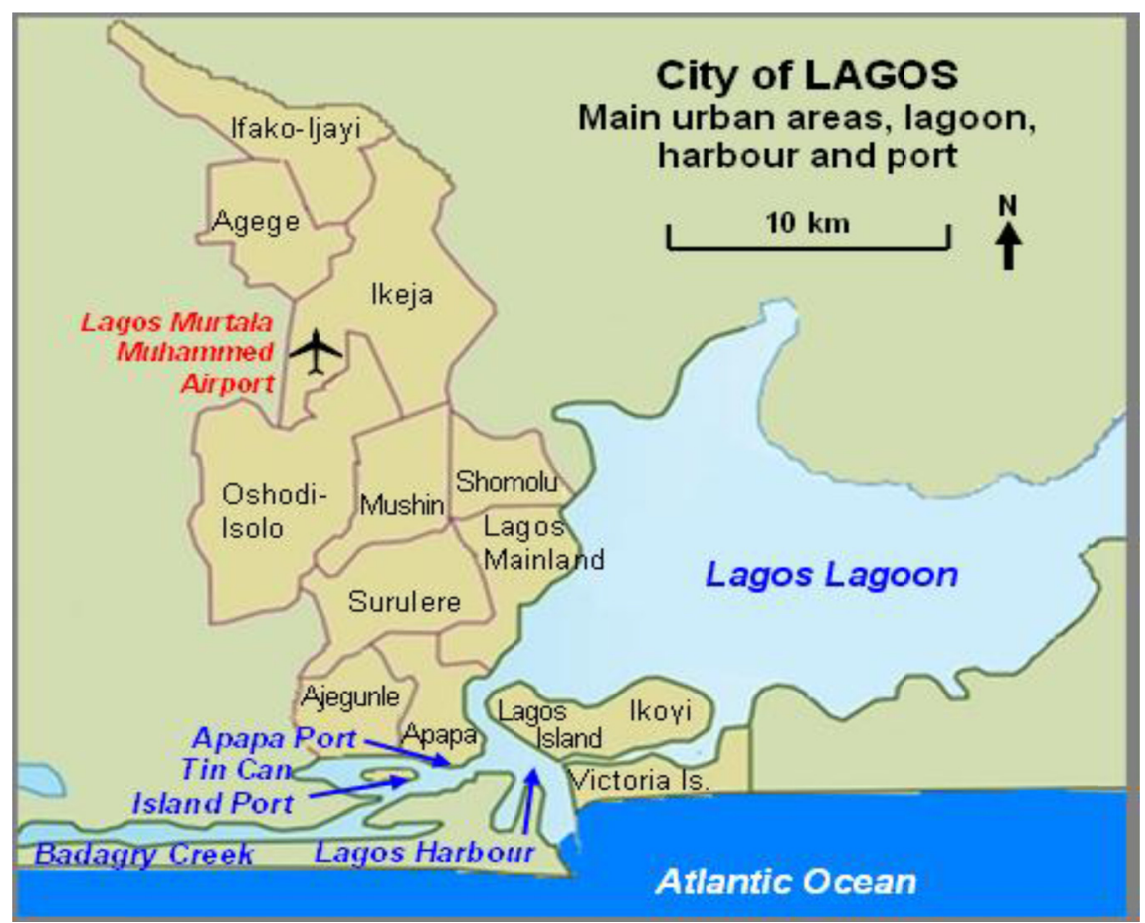

Figure 2. The map of Lagos megacity

Source: Commons. Wikimedia.org/wiki/File:Lagos_Map.PNG

The rapid increase in Lagos population is believed to be due to two factors- natural increase (birth) and net migration (Aluko, 2010). Unfortunately, the large population is confined to a relatively small land mass of $999.6 \mathrm{~km}$. The spatial growth of Lagos actually rose from $3.97 \mathrm{~km}^{2}$ in 1866 to about $1000 \mathrm{~km}^{2}$ in 2006 , yielding a density of 10,000 to 15,000 persons $/ \mathrm{km}^{2}$. This large population is sustained by the informal sector that accounts for more than $70 \%$ of the urban economy (UNDP, 2000). Though Lagos accounts for the bulk of Nigerian industries $(592,010)$, the rate of industrial growth of the city is only $5 \%$ (Oresanya, 2008). Poverty rate is one of the highest in the world. According to UNDP (2003), 51\% of the male and $54 \%$ of the female residents in Lagos are poor and live in shanties. 


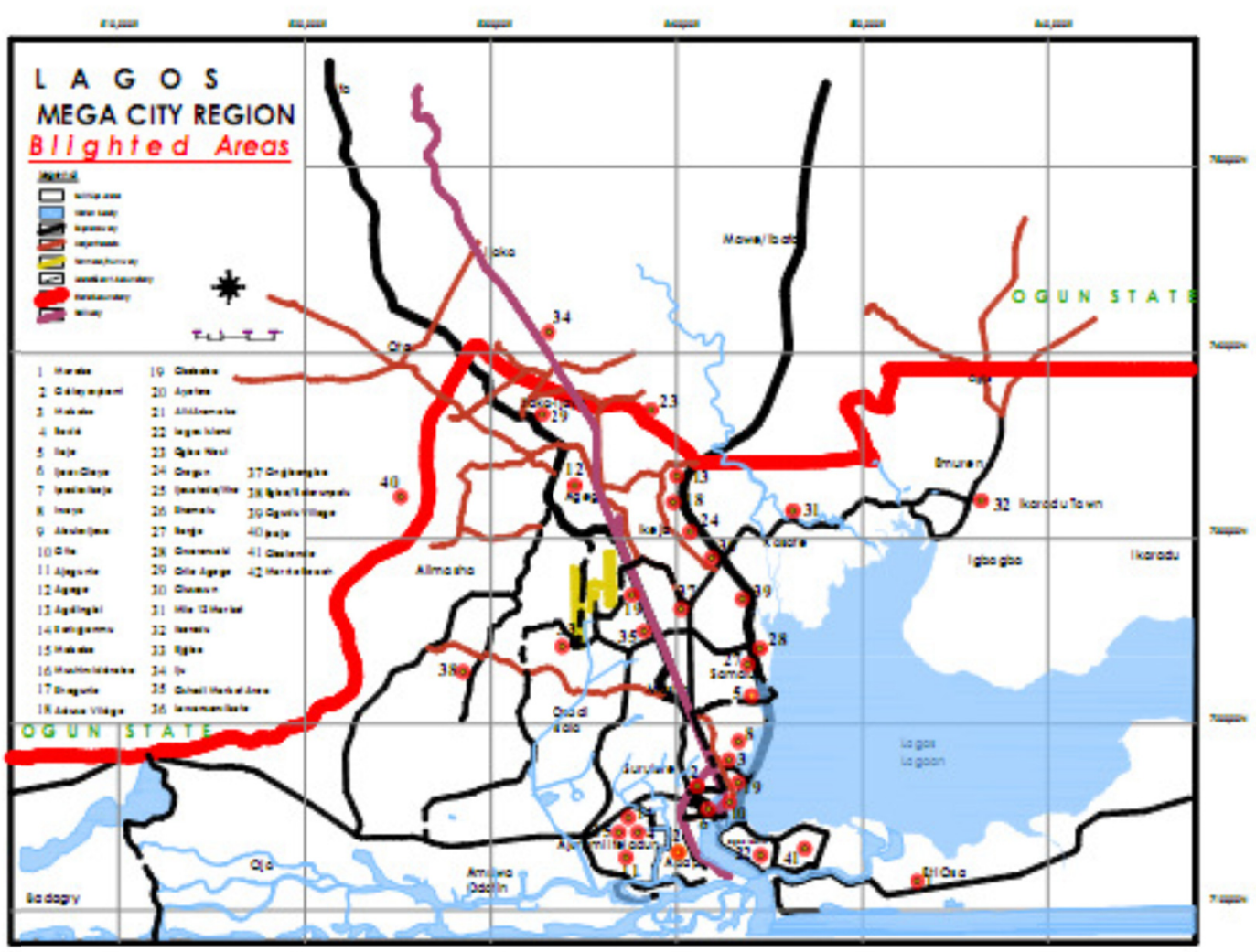

Source: SNC-Lavalin Report, 1995.

Figure 3. Map of Lagos megacity showing some popular slums

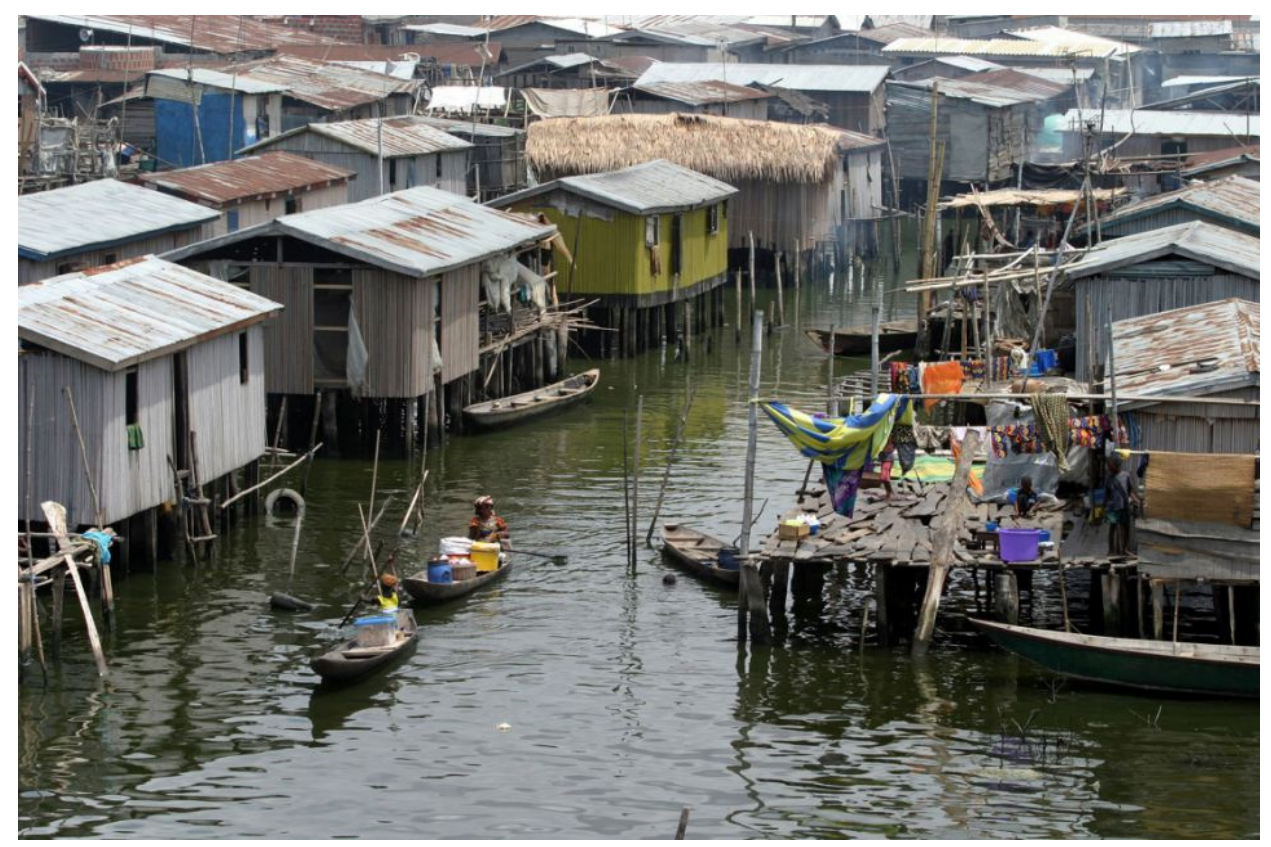

Figure 4. Makoko: A slum on stilts in the Lagos Lagoon

Source: Commons. Daily Mail. www.dailymail.co.uk/../Slum-stilts-A-mother-baby-paddles-dirty-oily-w. 
Lagos is a city of slums, harbouring not less than 100 of such settlements (Adelekan, 2009 \& Ilesanmi, 2010) ( figure 3 shows the map of Lagos depicting some of the slums of the city while figure 4 shows the popular Makoko slum that sits pretty on stilts inside Lagos lagoon). In terms of waste generation, Lagos is expected to produce 21,140 metric tonnes of waste daily by 2020 at a generation per capita (GPC) of $0.7 \mathrm{~kg} / \mathrm{per}$ hour/day (Oresanya, 2008). The bulk of these wastes is dump in landfills, since recycling is just beginning to take root in Lagos. With the enormous pressure on buildable land, it is becoming extremely difficult to get land for waste disposable. In 1945 only 4 tonnes of waste per day was generated and evacuated by only one truck, by 1967 only 180 tonnes per day was produced and only two trucks were engaged in the evacuation. However, by 2020, the 21,140 tonnes per day waste of Lagos shall need 1057 trucks to evacuate (see Table 3)! To solve this problem, Lagos required investment to the tune of about $\$ 30$ billion ( $\$ 150$ million) and $\$ 40$ billion ( $\$ 200$ million) in capital and recurrent expenditure respectively between 2008 and 2011. Only 8\% of the total solid waste generated in Lagos could be evacuated as compared to figures of $90 \%$ and $100 \%$ recorded by Tehran (Iran) and Los Angeles (USA) respectively (Decker, Elliot, Smith., Blake \& Rowland, 2000).

Table 3. A synopsis of Lagos solid waste management

\begin{tabular}{llllll}
\hline Year & Area & Population & Generation Rate/Day & Ton/Day & Trucks \\
\hline 1945 & $>200 \mathrm{~km}^{2}$ & 40,000 & $0.1(\mathrm{E})$ & $4+$ & 1 \\
1967 & $1,200 \mathrm{~km}^{2}$ & $1,500,000$ & $0.12(\mathrm{E})$ & 180 & $6(2$ Trucks $)$ \\
1976 & $10,000 \mathrm{~km}^{2}$ & $3,200,000$ & 0.2 & 640 & $100(35$ Trucks $)$ \\
1990 & $35,000 \mathrm{~km}^{2}$ & $5,000,000$ & 0.25 & 1250 & $210(70$ Trucks $)$ \\
2006 & $<40,000 \mathrm{~km}^{2}$ & $18,000,000$ & 0.4 & 7200 & $1200(400-500$ Trucks $)$ \\
2008 & $<40,000 \mathrm{~km}^{2}$ & $18,000,000$ & 0.5 & 9000 & $1500(550-650$ Trucks $)$ \\
2015 & $<60,000 \mathrm{~km}^{2}$ & $23,000,000$ & 0.7 & 16,100 & $2500(800$ Trucks $)$ \\
2020 & $<60,000 \mathrm{~km}^{2}$ & $30,200,000$ & 0.7 & 21,140 & $(1,057$ trucks $)$ \\
\hline
\end{tabular}

Source: Lagos State Waste Management Authority.

Beside waste, Lagos has one of the poorest road net-works in the world and traffic hold-ups are the common order of the day. Commuting from residential areas to places of work is a burdensome experience for Lagos residents and this transfer to loss of productive hours.

\subsubsection{Abuja}

Abuja is the capital of Nigeria, located between latitude $8^{\circ} 25^{\prime} \mathrm{N}$ and $9^{\circ} 25^{\prime} \mathrm{N}$ and longitude $6^{\circ} 45^{\prime} \mathrm{E}$ and $7^{\circ} 45^{\prime} \mathrm{E}$, at the heart of the country (see Figure 5). The Federal Territory is bordered by four states, Kaduna to the North, Nassarawa to the East, Niger to the West and Kogi to the south. Abuja, like Brasília in Brazil, is one of the purpose-built cities with a well conceived master plan aimed at removing all anticipated bottlenecks in her future development. Abuja city was designed to be built in phases within a stipulated time frame, and physical occupation was to be in 1996. However, and perhaps for policy expediency, movement to the city from Lagos came sooner, in 1991. That meant that at the time of occupation, the city was not ready to take the influx of persons, anticipated and unanticipated (Jibril, 2006). 


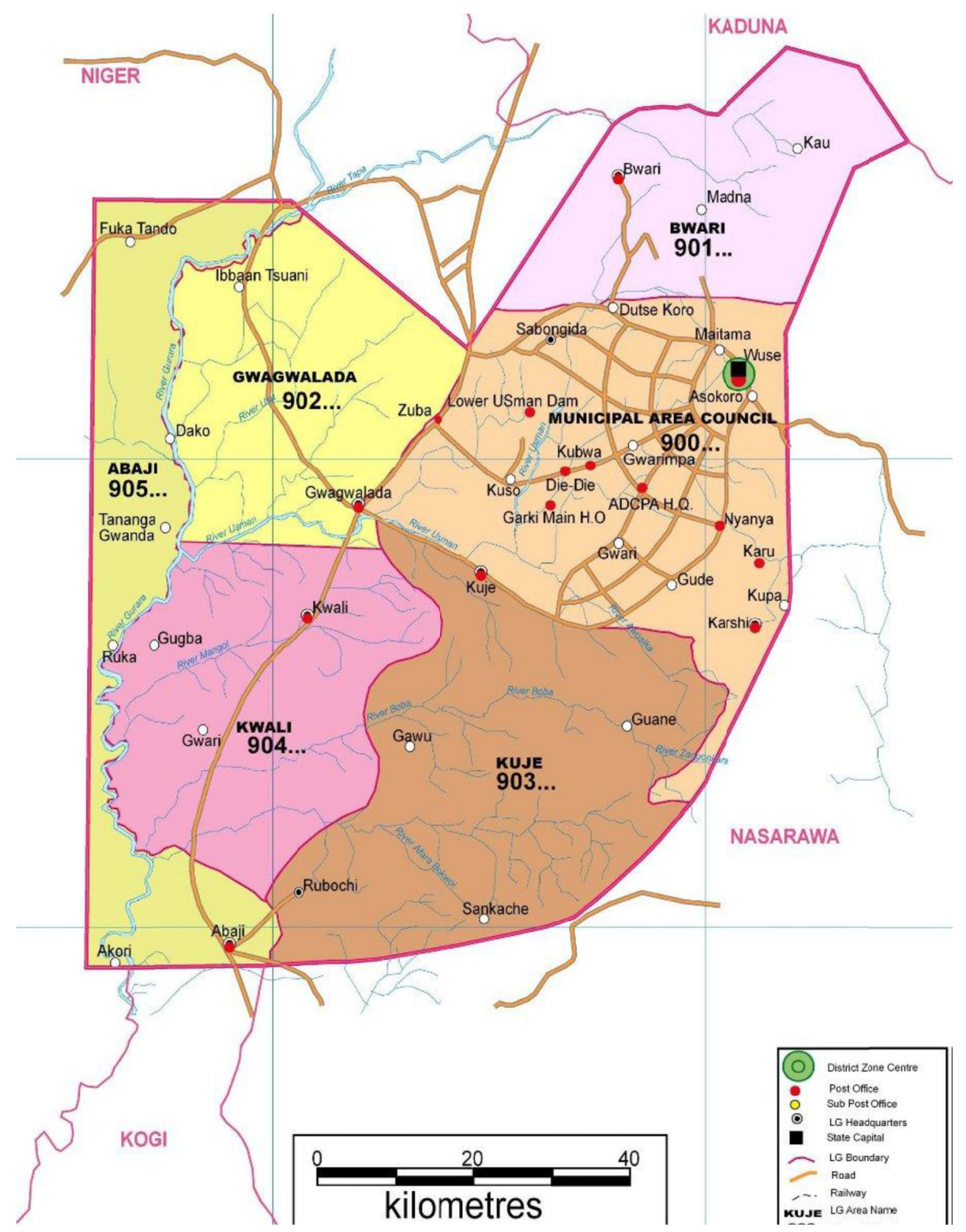

Figure 5. the map of Abuja Capital Territory

Source: Commons. https://www.google.com.ng/

Moreover, the government's earlier plan to entirely relocate the indigenous population suffered a setback because of poor estimation of the population involved (Jibril, 2006). This poor start led to the emergence of hurried squatter settlements to accommodate both construction workers who built the city and the civil servants who came in from Lagos. Accompanying this influx were members of the informal sector who came into town to take early strategic business advantages.

Abuja occupies the enviable position of being one of the fastest growing cities on earth, with a growth rate of $20 \%$ - 30\%, population of 778,561 and a density of 1092 persons per kilometre (Lagos, 2010). The Act that created the territory vested the ownership of a total of $8,000 \mathrm{~km}^{2}$ of land on the Federal Government to be designated and used as the Federal Capital Territory. (Jibril, 2006). The master plan of Abuja was designed by International Planners Association, a consortium of three American firms: Planning Research Corporation, Wallace, McHorg, Robert and Todd and Archisystems, and was planned to be built in phases, with each phase being fully developed (infrastructural) before occupation (Abuja, 2010). Phase 1 comprised 5 districts; Central, Garki, Wuse, Maitama 
and Asokoro. Phase 2 also had 5 districts; Kado, Durumi, Gudu, Utako and Jabi. The third phase has the districts of Mabushi, Katampe, and Gwarimpa. Abuja also has sub-urban districts like Nyanya, Karu, Gwagwalada, Kubwua and Jukwoyi, alongside satellite cluster settlements at Lugbe, Chika, Idu, Karumi and others. These settlements make Abuja a sprawling city where commuting is now a problem few years after occupation. Beside the districts of the $1^{\text {st }}$ phase that were developed before settlements, most other developments of other phases that followed had to involve the forced eviction of squatters.

Abuja has become a city of sprawl and suburban squatter settlements, and the growth of these slums far outstretch the capacity of the Ministry of Federal Capital Territory to handle. The blights of these settlements render irrelevant the argument for the relocation of the capital from Lagos. Ajegunle, Lagos notorious blight zone, is being reproduced at Nyanya, Jabi, Garki and others with vigour and vitality. As at 2004 some 26 squatter settlements (slums) were identified in Abuja, covering more than 2000 hectares (see Table 4) (Jibril, 2006 \& Daniel, Wapwera, Akande, Musa, \& Aliyu, 2015). The suburbs and even the inner-city of Abuja reproduced the same state of misery and squalor that made Lagos notorious - lack of roads, unmanageable traffic congestion, filth and crushing poverty among others.

Table 4. Slum settlements of Abuja

\begin{tabular}{lllll}
\hline ID & Name & Type & Area $($ Ha) & District \\
\hline 1. & Bakasi Market & Market & 20.7 & Central Area \\
2. & Zone 3 & Mechanics & 5.9 & Wuse I \\
3. & Garki & Village/market & 19.0 & Garki II \\
4. & Guzape & Village & 225.8 & Guzape \\
5. & Garki village & Market & 14.7 & Gudu \\
6. & Apo & Village/market & 46.8 & Durumi, Gudu \\
7. & Durumi & Squatter & 32.3 & Durumi \\
8. & Mabushi & Squatter/market & 15.5 & Mabushi \\
9. & Katampe & Village & 13.9 & Katampe \\
10. & Gaduwa & Village & 9.4 & Gaduwa \\
11. & Dutse & Squatter & 189.0 & Dutse \\
12. & Dutse & Village & 21.1 & Dutse \\
13. & Wumba & Village & 5.3 & Mumba \\
14. & Mada & Squatter & 165.4 & Outside FCC \\
15. & Kurbo & Squatter/market & 54.5 & Outside FCC \\
16. & Kuchigoro & Old village & 3.7 & Kukwaba \\
17. & Kuchigoro ext & Squatter & 59.9 & Kukwaba \\
18. & Karmajiku & Squatter & 37.9 & Kukwaba \\
19. & Wuye & Squatter & 2.4 & Wuye \\
20. & Jabi & Squatter & 14.0 & Jabi \\
21. & Jabi & Squatter & 4.3 & Jabi \\
22. & Jabi/Dakibiyu & Squatter & 51.6 & Jabi, Dakibiyu \\
23. & Utako & Squatter & 11.9 & Utako \\
24. & Karmo & Squatter & 524.0 & Karmo \\
25. & Gwarinpa & Squatter & 408.0 & Gwarinpa I \\
26. & Dape & Squatter & 455.0 & Dape \\
\hline
\end{tabular}

Source: Federal Capital Territory, Final report stage 1, AGIS, 2004. (10 to 15 yrs ago)

A fundamental poser is whether Abuja was designed to meet the sustainability criteria? Put bluntly, was Abuja 
designed to be a sustainable/eco-city? Were the economic, social and environmental components brought into consideration at the conceptual stages of the design of the city? Was Abuja designed to accommodate the poor as well? How much of the indigenous people's participatory inputs were brought into the design of the city? The common answer to all these questions is no. Perhaps Gro Harlem Brundtland's 'sustainable development' concept of 1987 was too early on world stage to influence the design of Abuja. The implication is that the Abuja we have is a city that is fossil energy-dependent, and elitist with expressways and massive and costly architectural and civil structures. The city's high speed ways made no provisions for bicycles for instance, the next most sustainable means of transportation to the human feet.

Abuja cannot pass the sustainable or eco-city test. The places of work and places of residences are rarely within walking distances. People have to move more than $50 \mathrm{~km}$ from Gwagwalada to the inner-city to work. Parks and green areas can only be found in the districts of Phase One. Other phases and sub-urban settlements cannot afford the luxury of open spaces. Unscrupulous land speculators dominate the property market, with cases of land and properties exchanging hands without proper titles. Abuja is for the rich. The gap between the poor and the rich gets wider by the day. The informal economies dominate the city with more than $70 \%$ of the population being involved. (UNDP, 2003).

The movement of people to Abuja is not abating and with a growth rate of between $20 \%$ and $30 \%$, Abuja would soon become a mega-city, a far cry from the expectations of the creators of the master plan who peg the population at an optimum of 3.1 million at full development (Jibril, 2006). With the flaws inherent in the design in the first place, and fluctuating policies and lack of commitment on the part of implementers, Abuja shall as well go down the line of Lagos (Nigeria) and Mumbai (India) - cities notorious for their sprawling slums.

\subsubsection{Comparison between Lagos and Abuja}

Although the growth rate of Abuja is extremely phenomenal (30 40\%, in barely three decades of its existence), the city shares other very crucial indicial similarities with Lagos. This is most evident in the number and sizes of their slums and the rate at which they emerge; as well as the rate of waste generation and management. Both cities have very high per capita rate of municipal solid waste generation of about $0.66 \mathrm{~kg} / \mathrm{day} / \mathrm{person}$ (Ayuba, Manaf, Sabrina, \& Azmin, 2013; Ogwueleka, 2009). They also have little or no modern infrastructure to manage these waste generated. Waste disposal in these cities is basically rudimentary, with reliance on poorly managed landfills. Re-cycling industry is yet to develop fully, the little attempt being private sector initiatives at Lagos. Abuja is yet to develop such an industry despite being a modern purpose-built city. The urban growth in Abuja could be likened to the situation in Lagos at the end of Nigerian Civil war in 1970, where there was a sudden massive influx of persons to the capital city from war-torn cities and villages of the East and other places. Abuja witnessed similar fate when the capital city was moved from Lagos in the eighties. The emergent urban problems are basically the same.

\section{Recommendations}

Most Nigerian cities have no master plans and those that have are not being implemented to the letters. Yet, nearly all of these cities show the potential of becoming mega-cities within a century given their population growth rates. Even at their present state of growth, they are hosts to squatters. In order to stem the slide to this degrading lifestyle and benefits from the bounteous opportunities offered by mega-cities the following steps are recommended:

1) Each of the Nigerian cities should have a new master plan or review the existing one to conform to the principles of sustainability.

2) The Nigerian government should not only adopt Local Agenda 21 in principles but provide the necessary institutional framework and incentives for its implementation, even at each of the more than 700 Local Government levels across the country.

3) Architects and urban planners should adopt sustainability approaches in designs for the cities and the homes, where the economic, social and environmental factors are brought in. That they could do by embracing the principles of trans-disciplinarily (involvement of experts across the spectrum of disciplines).

4) Architects should design affordable houses that meet the sustainability demands - houses that reduce or minimize clients' over-dependence on fossil energy, minimize the use of water, and embrace materials that use minimal embodied energy and are generally in agreement with the local ecology. For instance, the Indian bamboo, a common building material in the area could be specified in place of timber and steel. 
5) The emergent Nigerian mega-cities must be such as would enhance the quality of life of their residents, guarantee their education (qualitative), preserve their culture and raise their economic status without compromising the environment, and in such a way as to guarantee the continued availability of such benefits for the future generation.

6) 'Sustainable architecture' should become a 'core' course in the schools of architecture in universities and polytechnics while the principles of sustainability should be taught across all the disciplines and tiers of education across the World.

\section{Summary and Conclusion}

Cities of over 10 million persons, classified by United Nation as megacities, have increased from one in the late fifties (New York) to 28 in 2014 (UN, 2014). Part of the problem is that the distribution of these cities is skewed towards the developing nations and emerging economies. As at today, Nigeria has one such city, Lagos, with many others bracing up to this status. Urban areas like Ibadan, Kano. Port Harcourt, Benin, Enugu, Kaduna and Maiduguri are already above one million residents. Abuja, though relatively young, has one of the highest levels of growth at about $30 \%$. These settlements are all potential megacities.

The major problem with Nigerian cities, just like most third world cities, is the absence of sustainable master plans that will guarantee the continued survival of these cities in the face of complex economic, social and environmental issues. Sustainability is a concept that is not yet embraced by the authorities in Nigeria. Nor are the citizens aware of its existence, content and relevance. The two-prune approaches to the entrenchment of sustainability development include mass education and enlightenment, referred to as bottom-up approach, and the enthronement of rules and their observance through civil/legal institutions, often referred to as top-down approach (Salama,. \& Ashukaikhat, 2006). These have to be embraced.

Architects and others involved in city planning and design have a big role to play as their decisions go a long way to determining how our natural, social and economic environments survive. The materials the architects specify in the design proposals are all derived from the physical environment, and the choice and manipulation of the design space affect the local ecology. A totally new approach to architectural practice has to be adopted if Nigeria would not be left out in this global survival race. Elsewhere in the developed world, a new discipline has taken its root in the practice of architecture, called 'sustainable architecture'. This is a paradigm shift in architecture. Thus, the teaching and practice of Architecture across the Globe must be such that should be rooted on the principles of sustainability.

\section{References}

Abuja. (2010). Retrieved from http://en.wikipedia.org/wiki/abuja/

Adelekan, I. O. C. (2009). Vulnerability of poor urban communities in climate change in Lagos, Nigeria, $5^{\text {th }}$ Urban Research Symposium.

Ahianba, J. E., Dimuna, K. O., \& Okogun, A. (2008). Built environment decay and urban health in Nigeria. Journal of Human Ecology, 23(3), 265.

Al-Akkham, A. J. M. (2012). Towards environmentally sustainability urban regeneration: a framework for Baghdad City centre. Journal of sustainable development, $5(9)$, 58-74. http://dx.doi.org/10.5539/jsd.v5n9p58

Aluko, O. E. (2010). The impact of urbanization on housing development: the Lagos experience, Nigeria. Ethiopian Journal of Environmental Studies and Management, 3(3), 64-73.

Angel, S., Sheppard, C. S., \& Civco, D. L. (2005). The dynamics of global urban expansion. Transport and Urban Development Department, The World Bank, Washington, D. C.

Ayuba, K. A., Manaf, L. A., Sabrina, A. H., \& Azmin, W. N. (2013). Current status of municipal solid waste management practices in FCT Abuja. Research Journal of Environmental and Earth Sciences, 5(6), 295-304.

Castells, M. (1996). The information age: economy, society and culture volume 1- The rise of the network society. Oxford: Blackwell.

Couch, C., \& Dennemann, A. (2000). Urban regeneration and sustainable development in Britain: the example of Liverpool. Roadwalks Patnership. Journal of cities, 17(2), 137-147. http://dx.doi.org/10.1016/S0264-2751(00)00008-1

Daniel, M. M., Wapwera, S. D., Akande, E. M., Musa,C. C., \& Aliyu, A. A. (2015). Slum housing conditions and 
eradication practices in some selected Nigerian cities. Journal of Sustainable Development, 8(2), 230-240. http://dx.doi.org/10.5539/jsd.v8n2p230

Decker, E., Elliot, S., Smith, F. A., Blake, D. R., \& Rowland, F. S. (2000). Energy and material flow through the urban ecosystem. Journal of Annual Review of Energy and Environment, 25, 685-740. http://dx.doi.org/10.1146/annurev.energy.25.1.685

Department of Environment, Local Government. (1980). Planning and Land Act, HMSO, London, section (136), 120.

Desai, N. (1999). Cultivating an urban eco-society. The United Nations Response. In T. Inoguchi, \& E. Newman (Eds.), Cities and Environment. New approaches for eco-societies. New York: United Nations University Press.

Dick, G. (2010). Sustainable (green) building: green building basics. Retrieved from http:///www.catrecycle.ca.gov/GreenBuilding/Greg Dick

Donk, V. M. (2006). Positive urban futures in Sub-Saharan Africa: HIV/AIDS and the need for a broader conceptualization (ABC). Environment and Urbanization, 18(1), 1555-177.

Esteve-Sendra, C., Moreno-Cuesta, R., Portates-Maianos, A., Magal., \& Royo, T. (2012). Bamboo, from traditional crafts to contemporary design and architecture. Procedia - Socisl and Behavioural Sciences, 51, 777-781.

Falade, J. (2010). 56 million Nigerians live in slums. The Punch, August 16, p. 64.

George, C. K. (2010). Nigeria: challenges of Lagos as a mega-city. Daily Independent. Retrieved from http://ARCHITECTURE\Documents $201002221420 . h t m l$

George, C. K. (2010). Nigeria: challenges of Lagos as a mega-city. Daily Independent.

Hui, C. M. (2002). Sustainable architecture. Retrieved from http://www.arch.hku.hk/research/BEER/sustain.htm

Ilesanmi, A. O. (2010). Urban sustainability in the context of Lagos mega-city. Journal of Geography and Regional Planning, 3(10), 240-252.

Jibril, E. U. (2006). Resettlement issues, squatter settlements and the problems of land administration in Abuja Nigeria's Federal Capital, paper presented at the $5^{\text {th }}$ FIG -Regional Conference held at Accra, Ghana, March 8-11, 2006.

Kati. (2014). Ideas for sustainable living: uses for bamboo in sustainable building. Retrieved from http://www.greenbuild.org/

Kraas, F., Aggarwal, S., Coy, M., Heiken, G., Marker, B., Nenonen, K., \& Yu, W. (2005). Megacities - our global urban future. Retrieved from http:///www.yearofplaneteath.org

Lagos. (2010). Retrieved from http://en.wikipedia.org/wiki/lagos/

Megacities. (2010). Retrieved from http://en.wikipedia.org/wiki/megacities/

Mourshed, M., \& Khattah, O. (2006). Green Architecture and the Politics of Climate Change. GBER, 5(3), 1-2.

Mumma, T. (1995). Reducing the embodied energy of buildings. Home Energy Magazine, January, 1995.

Neuman, M. (2005). The compact city fallacy. Journal of Planning Education and Research, 25, 11-26. http://dx.doi.org/10.1177/0739456X04270466

Newman, P. (2006). The Environmental impact of cities. Environment and Urbanization, 18(2), 275-295. http://dx.doi.org/10.1177/0956247806069599

Obia, A. E., \& Okon, H. E. (2010). Sustainable architecture: the challenge of the Nigerian architect in the $21^{\text {st }}$ century. Paper presented at the NIA 50 $0^{\text {th }}$ Anniversary Celebration, South South Zonal Conference held at Civic Centre, Port Harcourt, July, 13-16.

Ogu, V. I. (2001). Stakeholders' partnership approach to infrastructure provision and management in developing world cities: lessons from sustainable Ibadan project. Habitat International, 20, 517-523.

Ogueleka, T. C. (2009). Municipal waste characterization and management in Nigeria. Journal of Environmental Health Science and Engineering, 6(3), 173-180.

Olumiji, J. (2009). Evolving a planning strategy for managing urban sprawl in Nigeria. Journal of Human Ecology, 25(3), 201-208. 
Oresanya, O. (2008). The Lagos megacity project: the solid waste management projects. Lagos: Lagos State Publishing.

Roodman, D. M., \& Lenssen, N. (1995). A building revolution: how ecology and health concerns are transforming construction. Washington DC: Worldwatch Institute.

Salama, A. M., \& Ashukaikhat, M. (2006). A trans-disciplinary approach for a comprehensive understanding of sustainable affordable housing. Global Built Environment Review, 5(3), 35-50.

Ujoh, F., Kwabe, I. D., \& Ifatimehin, O. O. (2010). Understanding urban sprawl in the federal capital city, Abuja: towards sustainable urbanization in Nigeria. Journal of Geography and Regional Planning, 3(5), 106-113.

UN. (2014). World urbanization prospects: 2014 revision. New York: United Nations.

UNDP. (2000). Overcoming human poverty Urban planet: Collective identities, governance and empowerment in megacities. Retrieved from www.irmg.coninx.stiftung.de/index

UNDP. (2003). Human development report. Retrieved from www.undp.org

WCED. (1987). Our common future. New York: World Commission and Environment and Development.

Whitehouse. (2005). Half of humanity set to go urban. Retrieved from $B B C$ News website

Wikipedia. (2014). Sustainable architecture. Retrieved from http://en.wikipedia.org/wiki/sustainable.architecture

Wooldridge, M. (2012). Booming bamboo: the next super material? BBC News magazine, Nicaragua.

\section{Copyrights}

Copyright for this article is retained by the author(s), with first publication rights granted to the journal.

This is an open-access article distributed under the terms and conditions of the Creative Commons Attribution license (http://creativecommons.org/licenses/by/3.0/). 